\title{
Poticanje razvoja medijske pismenosti u ranom i predškolskom odgoju i obrazovanju
}

Stručni rad - primjer dobre prakse _ DOI 10.22522/cmr20190152 _ primljeno 19. siječnja 2018. UDK: 37:373.2-053.4 $003.02: 316.774$

\section{Kristina Ljubić Nežić}

Dječji vrtić Vrbovec, Vrbovec, Hrvatska.

E-adresa: kristinaljubich@gmail.com

\section{Sažetak}

Cilj projekta je poticanje medijske pismenosti djece u ranoj i predškolskoj dobi te uspostavljanje temelja za daljnji razvoj u suvremenom medijskom okruženju. Dob djece se navodi kao jedan od ključnih čimbenika o kojima ovisi na koji će način mediji utjecati na dijete. Mediji imaju veći utjecaj na mlađu djecu, ali, istovremeno, mlađa djeca vide posredstvo roditelja kao pozitivno i poželjno. To čini priliku i izazov za profesionalce koji rade s djecom u ranom i predškolskom odgoju za poduzimanje ranih intervencija te oblikovanje dječjih navika korištenja medijskog sadržaja. Projekt uključuje sve čimbenike koji imaju neposredan kontakt s djecom u kontekstu odgojno-obrazovnih ustanova - djecu, roditelje i odgojitelje. Medijski sadržaji korišteni su kao poticaj u radu s djecom, a s roditeljima i odgojiteljicama održana je radionica o utjecaju medija na djecu. Rezultati provedene ankete s roditeljima i odgojiteljima ukazuju na potrebu njihove edukacije u svrhu poboljšanja vlastitith kompetencija kao temelja za daljnji razvoj medijske pismenosti djece.

KIjučne riječi: djeca, odgojitelji, roditelji, rani i predškolski odgoj, medijska pismenost 
Današnja djeca odrastaju u svijetu ubrzanog razvoja tehnologije i znanstvenih postignuća te neprestanih promjena koje taj razvoj nosi. Promjene se događaju na globalnoj razini, u širem društvenom kontekstu i utječu na mikrookruženja, ovisno o kulturnim specifičnostima i navikama pojedinaca. Medijsko djetinjstvo (Mikić, 2002) ne možemo zanemariti kao pojavu koja danas doista poprima sve veće razmjere. S obzirom na nemogućnost usklađivanja radnih i obiteljskih obaveza roditelja, mediji ih često zamjenjuju u ulozi prenošenja obrazaca ponašanja pa sintagma „mediji kao odgojitelji mlađih generacija“ (Ciboci, Kanižaj, 2011, str. 12) ima puno značenje u sadašnjosti, a pretpostavka je da će imati i sve snažniji utjecaj u budućnosti. Djeca predškolske dobi „najviše vremena provode gledajući televiziju“ (Ilišin i sur., 2001; Mikić, Rukavina, 2006; Sindik, 2012 prema Bartaković, Sindik, 2016, str. 95). Dakle, televizija je najkorišteniji medij u ranoj i predškolskoj dobi, ali i vjerojatno najjednostavniji i najpristupačniji uređaj pa stoga djeluje kao „važan čimbenik suvremene socijalizacije te ima značajnu ulogu u procesu učenja, vrijednosti i ponašanja kod djece“ (Bartaković, Sindik, 2016, str. 96). No, uz televiziju, roditelje „zamjenjuju“ i druga medijska sredstva poput mobilnih uređaja, računala ili tableta koje djeca koriste samostalno. Iako su mediji dostupni djetetu $\mathrm{u}$ ranoj i predškolskoj dobi, medijski odgoj provodi se tek u osnovnoj školi u okviru nastave Hrvatskoga jezika kada djeca već dolaze s razvijenim navikama korištenja medijskih uređaja i sadržaja. Do polaska u školu djeca već imaju oblikovane spoznaje o medijima i sadržajima kojima su bili izloženi u prethodnom razdoblju, dolaze s oblikovanim stavovima, vrijednostima i načinu ponašanja. Ako se uzmu u obzir psihološke karakteristike djeteta $\mathrm{u}$ kontekstu utjecaja medija te dostupna istraživanja, iako malobrojna, ukazuje se obaveza poduzimanja intervencija $u$ okviru institucija ranog i predškolskog odgoja. S obzirom na dostupne sadržaje, nužno je djecu opskrbiti vještinama, sposobnostima i znanjima, odnosno medijski ih opismenjavati i stvarati naviku svrhovitog korištenja medijskog sadržaja s ciljem proširenja vlastitih mogućnosti u istraživanju okoline i svladavanja izazova. Nameću se mnoga pitanja prema svima koji neposredno sudjeluju u odgoju i obrazovanju djece. Jesu li roditelji svjesni utjecaja medija na djecu i kako sami koriste medijske sadržaje do toga kako mi, kao profesionalci, koristimo medije; širimo li možda i sami, nesvjesno, brojne stereotipe, uvjerenja, stavove i obrasce ponašanja koji su posljedica vlastite izloženosti medijskim sadržajima; i konačno, jesmo li spremni raditi na vlastitim kompetencijama. U odnosu na dijete, jedan od načina i za profesionalce i 
roditelje je, prema Sindiku (2012), postavljanje temeljnih pitanja medijskog odgoja: „u kojim je situacijama smisleno koristiti pojedine vrste medija“ te „znati kako mediji djeluju na krajnje korisnike, posebno djecu“ (Glasovac, 2010 prema Sindik, 2012, str. 8). Pokušaji utjecaja na roditelje i osvještanje njihovih navika moraju biti popraćeni shvaćanjem izazova roditeljstva $u$ današnjem svijetu i indvidualnih potreba i mogućnosti s obzirom na kontekst $u$ kojemu žive i djeluju. Svakako treba pokazati razumijevanje za situacije u kojima se roditelji nalaze i pronaći način za optimalne, moguće, primjenjive postupke i korake u kreiranju uvjeta za stvaranje poticajnog okruženja za poticanje medijske pismenosti djece. Istovremeno, potrebno je pratiti interese djece te pokušati iskoristiti tehnologiju na smislen i njima blizak način, prilagođen dobi i mogućnostima kako bi ona mogla ostvariti osjećaj uspjeha u svladavanju izazova i stjecanju novih spoznaja te raditi na procesu spoznavanja svojih indvidualnih načina učenja.

\section{Mediji, medijska pismenost, medijske kompetencije, medijski odgoj, medijsko obrazovanje - odredivanje pojmova i njihov odnos}

Kada se govori o medijima, većinom se podrazumijeva kontekst novih medija i primjena različitih tehnoloških postignuća i uređaja koje koristimo kako bi pristupili sadržajima. Zgrabljić Rotar (2005), kada govori o načelima medijske pismenosti, naglašava da treba uzeti u obzir sve vrste medija, a ne samo nove medije te ih promatrati kao cjelinu, ali i zasebno proučavati učinke pojedinih medija kako na društvo tako i na pojedinca. Svakako se može utvrditi da su mediji ključni u procesu socijalizacije te snažno sredstvo u oblikovanju stavova i mišljenja. Pojava internetske mreže dovela je do brzog širenja informacija, ali i jednako tako do njihovog brzog zastarijevanja. Upravo zbog velike količine različitih informacija u kratkom vremenskom periodu teško je naći ravnotežu između „davanja poticaja radu i razvoju medija i kreiranju mehanizama za zaštitu od štetnih medijskih utjecaja“ (Zgrabljić Rotar, 2005, str. 5). Potrebne su određene vještine da bi mogli uspješno svrstavati i filtrirati sve poruke primljene putem medija.

Definicija medijske pismenosti uspostavljena je još 1993. godine kada je definirana kao „sposobnost pristupa, analize, vrednovanja i odašiljanja poruka“ (Aufderheide, 1993 prema Malović i sur., 2014, str. 148). Mirela Tolić (2009) označava medijsku pismenost kao „najnižu razinu svladavanja osnovnih vještina kod prepoznavanja vizualnih simbola 
i rada na računalima te drugim medijskim sredstvima“ (Tolić, 2009, str. 100). Ista autorica jasno pojašnjava razliku i odnos između pojmova medijske pismenosti, medijske pedagogije, medijskog odgoja i medijskog obrazovanja. Medijska pedagogija proučava socijalizacijske utjecaje na djecu i mlade, a uključuje medijsku pismenost, medijske kompetencije, medijsku didaktiku i metodiku te medijsku etiku. Da bi medijski odgoj bio uspješan, potrebno je raditi na svim poljima medijske pedagogije. Čitav niz faktora utječe na svakog pojedinca u njegovom doživljaju, shvaćanju, a na kraju u upotrebi medija i prikladnom odabiru odgovarajuće vrste i načina komuniciranja. Prema svemu ovome, svakako djeci treba pružiti mogućnost da koriste medije i da oni budu resurs i potpora strategijama učenja, daljnjem razvoju i snalaženju u svakodnevnoj komunikaciji. Medijska kompetencija može se definirati kao sposobnost kretanja po svijetu medija na kritički, reflektivan i nezavisan način s osjećajem za odgovornost, rabeći medije za nezavisno i kreativno izražavanje (European Centre for Media Competence prema Malović i sur., 2014, str. 139). Dakle, medijske kompetencije daju osobama mogućnost da medijske poruke identificiraju u određenom širem kontekstu, ovisno o globalnim, ekonomskim, socijalnim, političkim i kulturnim faktorima i shvate poruke uzimajući sve čimbenike $\mathrm{u}$ obzir. Taj proces ovisi o raspoloživim medijskim sredstvima, događa se u izlaganju medijima i podrazumijeva korištenje istih za razvoj pojedinca. Medijski odgoj trebao bi učiti tumačenju i proizvodnji poruka te odabiru najpogodnijih medija za komunikaciju (Vijeće Europe prema Malović i sur., 2014, str. 140). Moglo bi se reći da je medijska pismenost prvi korak u gradnji medijskih kompetencija i baza za daljnje snalaženje u svijetu medija. Dijete u ranoj i predškolskoj dobi pokazuje interes za sve vrste medija: za tiskane (slikovnice, priče, enciklopedije, dječji časopisi), radio, televiziju i nove medije. S obzirom na to da ih je nemoguće izolirati iz svijeta novih medija, svakako ih je potrebno koristiti zajedno s ostalim vrstama, kombinirati njihovu upotrebu kako bi djeca postupno stvarala širu sliku i dobila više perspektiva u razvoju medijske pismenosti.

\subsection{Faktori koji utječu na medijsku pismenost djece}

Kada se govori o čimbenicima koji utječu na dijete, većina se znanstvenika slaže oko ključnih čimbenika koji imaju utjecaj na medijsku pismenost djece, odnosno na učinak medijskog sadržaja na dijete. Sindik (2012) ističe kako se svakako u obzir moraju uzeti kulturološke razlike u određenom području, ali i utjecaj društvene okoline na dijete. Prema istome autoru, ključni faktori su trajanje (vremenski period proveden $u$ korištenju medija), način (kako se koriste mediji), sadržaj (primjerice igrani filmovi, crtani filmovi, 
obrazovni programi) i dob djece. Ministarstvo obrazovanja Sjedinjenih Američkih Država (2016) izvještava o tri specifična čimbenika koje treba uzeti u obzir kada se govori o upotrebi medija. Osim sadržaja, oni ističu ključnu ulogu konteksta (u kojim uvjetima dijete koristi medijske sadržaje, što se događa neposredno prije i nakon korištenja sadržaja) te individualne karakteristike djeteta. Osobne karakteristike pojedinca i obiteljski odgoj ističu i drugi autori (primjerice Ciboci i sur., 2011), kao i potrebu uključivanja roditelja i drugih odraslih te njihovu interakciju s djetetom tijekom korištenja medija. Dakle, iako postoje ključni čimbenici, oni još dodatno ovise o kulturološkim karakteristikama, širim socijalnim uvjetima i obiteljskom okruženju u kojem dijete odrasta.

Dob je ključno polazište kada se govori o medijskom opismenjavanju djece rane i predškolske dobi. Istovremeno je to prilika, ali i izazov, za oblikovanje medijske pismenosti, kako djece u ranoj i predškolskoj dobi, tako i njihovih roditelja. Mlađa djeca više vjeruju medijima (Bartaković, Sindik, 2016; Ciboci i sur, 2014; Sindik, 2012) jer njihove „kognitivne i emocionalne sposobnosti te sposobnosti moralnog rezoniranja nisu dovoljno razvijene da samostalno procesuiraju poruke na način koji ih štiti od negativnih efekata“ (Potter, 2013 prema Bartaković, Sindik, 2016, str. 97). S druge strane, prema Ciboci i sur. (2014), postoji pozitivan stav prema roditeljskim intervencijama i sugestijama. Mlađa djeca žele roditelje kao partnere u igri i aktivnostima, a samim time traže potvrdu i mišljenje o onome što čine te promatraju roditelje kao model za ponašanje, oblikovanje stavova $\mathrm{i}$ doživljaj okoline. Ono što roditelji čine djeca smatraju ispravnim, bez obzira na to je li to doista prikladno. To su i glavni razlozi za obvezu ranih intervencija i stvaranje pravilnih medijskih navika.

\subsection{Roditeljska medijacija}

Neovisno o tome jesu li djeca uključena u programe ustanova, roditelji su najvažniji čimbenik u djetetovu životu u predškolskoj dobi. Mnogi autori ističu ulogu roditelja kao posrednika u korištenju medija, ali i navikama korištenja medijskog sadržaja kod djece koje su ekvivalentne navikama unutar obitelji (Mikić, 2002; Sindik, 2012; Ciboci i sur., 2014). Već spominjano medijsko djetinjstvo (Mikić, 2002) današnja je stvarnost i gotovo je nemoguće izolirati djecu od medija. „Primarni medijski odgojitelji“ (Sindik, 2012, str. 9) djeteta su roditelji i svojim primjerima i načinima korištenja tehnologije daju prva iskustva djeci. Sanja Bartaković i Joško Sindik (2016) označavaju roditeljsku medijaciju kao bilo koju strategiju koju roditelji koriste da bi kontrolirali, nadgledali ili interpretirali 
sadržaj medija djeci (Wareen, 2001 prema Bartaković, Sindik, 2016, str. 97). Što su roditelji bolje informirani, veća je mogućnost da će posredovati i biti uključeni u razvoj medijskih navika kod djece. Bolja informiranost pretpostavlja i medijsku pismenost roditelja i veću mogućnost da će roditelji intervenirati i posredovati pri korištenju medija kod svoje djece. S obzirom na rezultate istraživanja (Ciboci i sur., 2014) koji upućuju na početak gledanja televizije u prvoj (35,9\%) i drugoj godini (39,9\%), nužno je početi već u vrtićima raditi is djecom i s roditeljima. Bartaković i Sindik (2016) govore o tri vrste medijacije. „Zajedničko gledanje televizije“ kao pasivni način konzumacije, označava samo fizičku blizinu roditelja; „ograničavajuća ili restriktivna medijacija“ $\mathrm{u}$ kojoj roditelji postavljaju pravila vezana uz trajanje, količinu i vrijeme gledanja te „aktivna (instruktivna ili poučna medijacija)“ koja podrazumijeva raspravu o sadržajima kojima su djeca izložena. Informiranost roditelja utječe na korištenje sve tri vrste medijacije, no smatra se da najviše koristi daje aktivna medijacija (Bartaković, Sindik, 2016; Ciboci i sur., 2014). Jača djetetov kritički odnos prema sadržajima, smanjuje strah kod djece te dolazi do prenošenja vlastitih stavova i vrijednosti, a s druge strane kod gledanja obrazovnih programa aktivnom medijacijom „poboljšava se djetetovo razumijevanje radnje, likova i poučnih sadržaja, razlikovanje mašte od stvarnosti i dosjećanje detalja iz obrazovnih programa“ (Bartaković, Sindik, 2016, str. 98). Važno je naglasiti da je riječ o procesu koji se razvija postepeno i doprinosi jačanju kritičkog odnosa prema medijskim sadržajima. Svakako je potrebno neprestano ponavljati i nadograđivati znanja, ovisno o dobi djeteta i mogućnostima razumijevanja. Ovi podaci samo potvrđuju važnost utjecaja na roditelje kao najvažnije čimbenike $u$ poticanju medijske pismenosti djece.

\subsection{Odnos nacionalnog kurikuluma i medijske pismenosti}

Rani i predškolski odgoj nije dio obaveznog školovanja. Od 2014. godine, prema Zakonu o predškolskom odgoju i obrazovanju (NN 94/13), obvezno je uključivanje djece u programe predškole za djecu godinu dana prije polaska u školu. S jedne strane imamo djecu uključenu u programe od rane dobi, a s druge djecu koja se tek u 6. i 7. godini uključuju u odgojnoobrazovne ustanove. Od 2014. godine svi vrtići u Hrvatskoj obavezni su, prema Nacionalnom kurikulu, provoditi vlastite kurikule. Kurikul se temelji na cjeloživotnom učenju i ključnim kompetencijama koje se razvijaju cjeloživotnim učenjem. Kroz preporuke i ključne dokumente Europske komisije (EC, 2007; EC, 2011) i Organizacije za ekonomsku suradnju i razvoj (OECD, 2001; OECD, 2006), rani i predškolski odgoj smatra se temeljem za daljnji razvoj pojedinca i temeljno polazište za cjeloživotno učenje. Cjeloživotno učenje i razvoj 
ključnih kompetencija temelj su „društva znanja“ za prepoznatljivi europski identitet u širem, globalnom kontekstu i baza za razvoj inovacija, napretka ljudskog potencijala i propulzivnosti na tržištu rada. Dijete „najprije uči u obitelji kao prvoj zajednici, a zatim i u sustavu ranog i predškolskog odgoja i obrazovanja koji služi kao nadopuna i podrška obiteljskom odgoju i skrbi o djetetu te osigurava 'širok raspon kratkoročnih i dugoročnih učinaka'“(EC, 2011,str.2).IStjepan Malovići sur.(2014) u svome radu povezuju obrazovanje s medijskom pismenošću kao „korak u velikom konceptu znanja“ (Malović i sur., 2014, str. 145). Ključne kompetencije za cjeloživotno učenje temelj su hrvatskog Nacionalnog kurikula za rani i predškolski odgoj i obrazovanje (MZOS, 2014). Digitalna kompetencija objašnjena je kao „upoznavanje $s$ informacijsko-komunikacijskom tehnologijom i mogućnostima njezine uporabe $u$ različitim aktivnostima. Ona je u vrtiću važan resurs učenja i alat dokumentiranja i pomoć u osposobljavanju djeteta za samoevaluaciju. Ta se kompetencija razvija u takvoj organizaciji odgojno-obrazovnog procesa vrtića u kojoj je i djeci, a ne samo odraslima, omogućeno korištenje računala u aktivnostima planiranja, realizacije i evaluacije odgojno-obrazovnog procesa." (MZOS, 2014, str. 28) Vrijednosti koje se promiču kroz Nacionalni kurikul (znanje, identitet, humanizam i tolerancija, odgovornost i autonomija te kreativnost) sadržane su i u definiciji medijskog odgoja. Kurikul, dakle, već u svojim postavkama sadrži temeljne zadaće medijske pedagogije, ali i medijskog odgoja kao šireg pojma. No, čitajući pojašnjenje digitalne kompetencije u Nacionalnom kurikulu svakako treba promišljati o redefiniranju pojma s obzirom na to da je riječ o vrlo uskom tumačenju u odnosu na medijski odgoj i obrazovanje. Digitalne kompetencije tek su jedan segment sveukupnog medijskog odgoja. Samo snalaženje i korištenje više opisuju tehničke kompetencije, zanemaruje se razvoj kritičkog mišljenja primjeren dobi djeteta u ranom i predškolskom odgoju.

Partnerski odnos jedno je od načela Nacionalnog kurikula pa je i zadaća profesionalaca osnaživanje kompetencija i međusobna potpora svih sudionika odgojno-obrazovnog procesa - djece, roditelja i odgojitelja. Nužno je i više pažnje posvetiti medijskoj pismenosti odgojitelja kako bi mogli dati potporu djeci i roditeljima i zajednički utjecati na medijsku pismenost djece. Mnogi autori spominju medijsku pismenost odgojitelja kao jedan od ključnih faktora za razvoj medijske pismenosti djece, ali i roditelja (Ministarstvo obrazovanja Sjedinjenih Američkih Država, 2016; Sindik, 2012; Glasovac, 2010; Zgrabljić Rotar, 2005). 


\section{Projelkt ul Dječjem vrtiću. Vrbovec}

Projekt je započeo krajem listopada 2017. godine. Ideja je bila obuhvatiti 23 djece u dobi od četiri godine i njihove roditelje. Uzimajući u obzir prethodno navedene teorijske postavke te postavke Nacionalnog kurikula za rani i predškolski odgoj i obrazovanje, djeci su ponuđeni poticaji u svakodnevnom radu u sklopu centara u obliku različitih materijala. Materijali i poticaji koji su ponuđeni rezultat su promišljanja u odnosu na dob djece: što bi djeci moglo biti poticajno i zanimljivo kao predmet istraživanja? Hoće li ponuđeni poticaji imati svrhu i koje ishode će postići? Kako će učiti putem medija? Kako djeca mogu proširiti svoja znanja o medijima? S roditeljima je održana radionica, a daljnja komunikacija i distribucija sadržaja i korisnih materijala odvijala se putem elektroničke pošte. Spontano je održana i radionica s odgojiteljicama Dječjeg vrtića Vrbovec. Razvojem projekta kasnije su obuhvaćena i djeca iz ostalih skupina u vrtiću (to se odnosi na izdavanje prvog broja Vrtićkog lista). Važno je naglasiti da su poticaji u skupini Pandice, u kojoj je provođen projekt, ponuđeni djeci bez jasnog i određenog smjera u kojem će aktivnosti odvesti nakon početne ponude materijala djeca su sama određivala smjer i daljnji tijek.

\subsection{Formiranje medijskog centra}

Stari dijelovi računala i računalne komponente postavljeni su u posebno formiran centar $u$ sobi dnevnog boravka (Slika 2), a plakati s fotografijama i dijelovima računala te slagalice i umetaljke raspoređene su u centar stolno-manipulativnih igara i centar za početno čitanje i pisanje. Već prvi dan, pri donošenju materijala, djeca su u razgovoru donosila određene zaključke. Za kućište računala nekoliko je dječaka u razgovoru zaključilo da je to radio i da isti takav imaju kod kuće (Slika 1). Idućeg dana postavljen je cijeli centar - monitori, tipkovnice, računalni miševi, prijenosno računalo i žice različitih dužina i debljina. Djeca su najprije oprezno obilazila centar, a onda započela igru. Prva igra bila je simbolička pretvorili su medijski centar u ured. „Radimo, na poslu smo. Na poslu ti se radi.“ (Slika 4) „Posa““ je potrajao dva dana. Možemo pretpostaviti da je igra započela zbog iskustva djece $u$ obitelji. Igru je inicirao dječak čija majka radi u uredu. Oprez u obilaženju i postupnom približavanju najprije tipkovnicama, a tek onda istraživanju ostalih dijelova, mogao bi se objasniti činjenicom da kod kuće vjerojatno ne mogu ili ne smiju na isti način koristiti računalnu opremu. Htjeli su se uvjeriti da je sve doista pripremljeno za njih. Nakon „uredskog posla“ krenuli su u istraživanje unutrašnjosti monitora. Monitorima su spajali žice kako bi ga „popravili“. Popravci su trajali tri dana (Slika 2 i Slika 3). Jedan je 

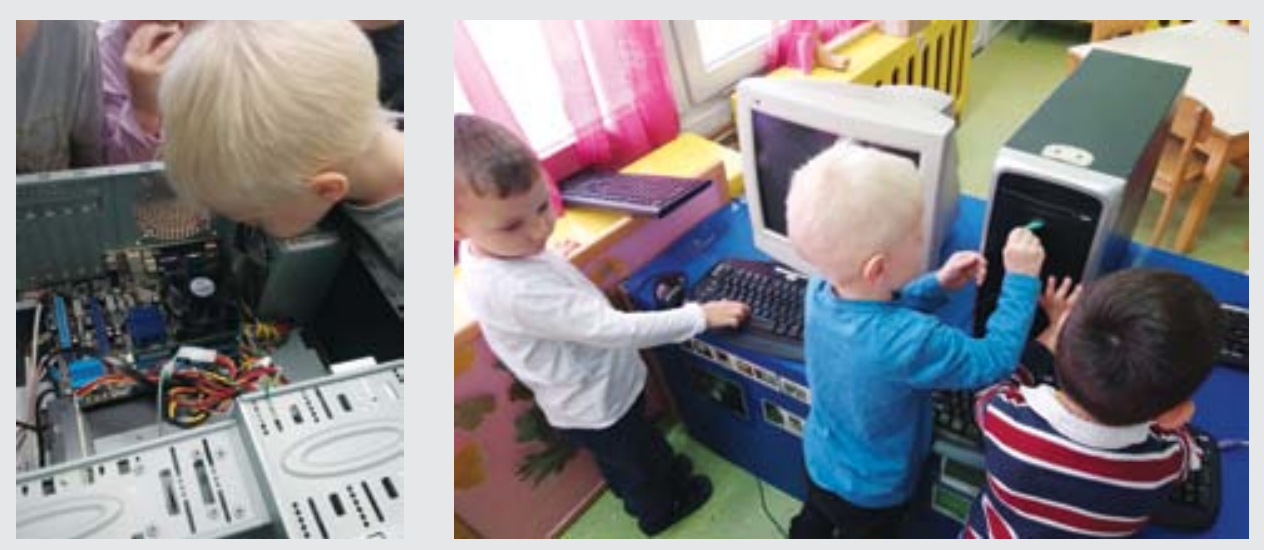

Slika 1.
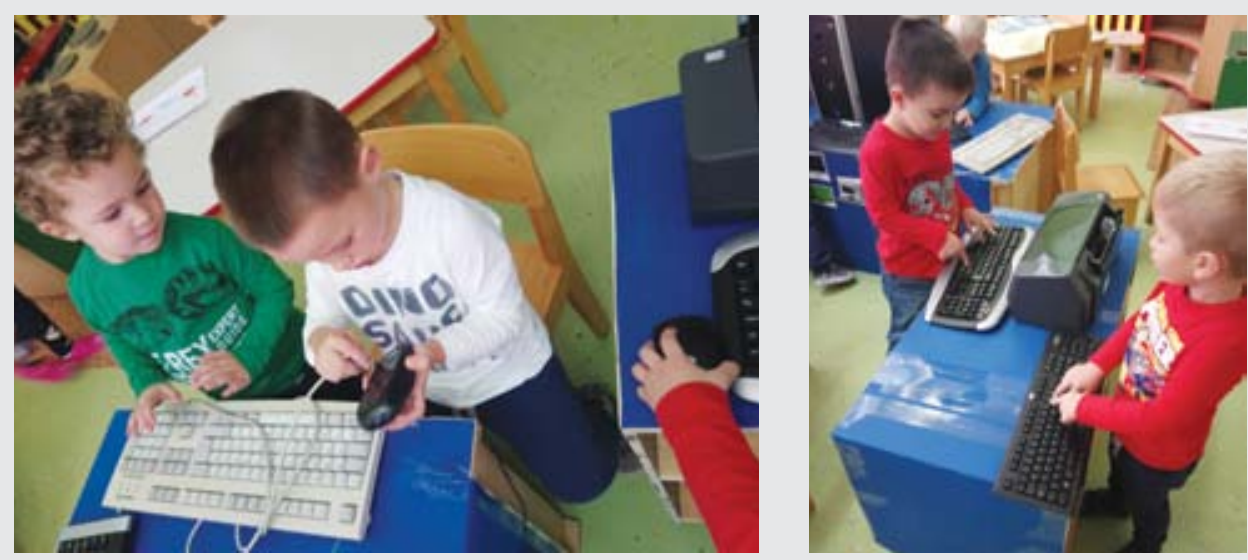

Slika 3.

Slika 4.

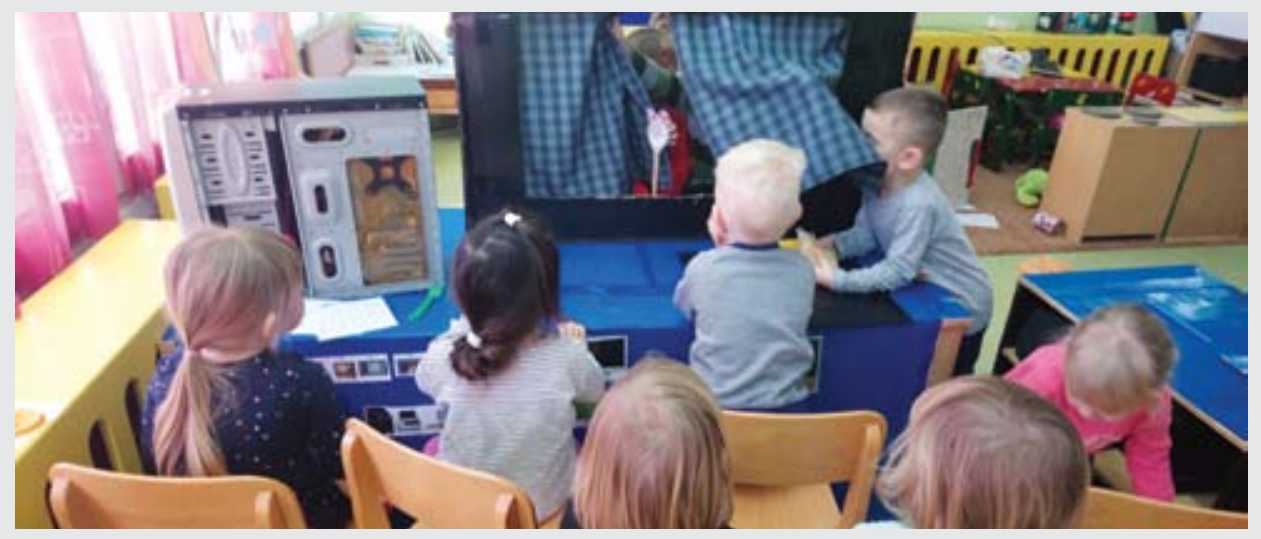

Slika 5. 
dječak izjavio kako popravljaju da bi mogli imati predstave. Osluškujući interes djece to je dalo poticaj za daljnju izradu i ponudu materijala. Od kartona je izrađen veliki ekran koji je nadograđen u centar, odnosno medijski centar je prerastao u centar za dramatizaciju (Slika 5). S obzirom na dječji interes za izradu predstave, nadopunili smo centar lutkama izrađenima od neoblikovanog materijala poput tkanina, drvenih dijelova, vune i špage. Umetaljke, pokrivaljke i različite slagalice u centru početnog čitanja i pisanja nisu toliko pobudile interes. Možda je to rezultat dječje znatiželje i motivacije za istraživanje materijala svim osjetilima. Više pozornosti posvećivali su uređajima i istraživanju njihove unutrašnjosti. Djeca su tijekom igre dogovarala slijed i način igre te su međusobno organizirali i podijelili poslove, što je izniman doprinos u procesu socijalizacije.

\subsection{Izrada kućišta računala}

Kućište računala za potrebe projekta posuđeno je od lokalnog informatičkog servisa. Nakon desetak dana uređaj je morao biti vraćen. Nakon odnošenja djeca su komentirala kako bi trebali novi „kompjuter“ jer neće moći održavati predstave. „Kompjuter“ smo izradili od kartona, novinskog papira i ljepila (Slika 6). Nakon sušenja, djeca su obojila kućište (Slika 7). Kako bi doista poprimio oblik „pravog“ računala, nakon nekoliko dana djeci je bio ponuđen alat i žice različitih debljina te različite plastične kutije manjeg formata i glinamol za spajanje unutar kućišta (Slika 8 i Slika 9).

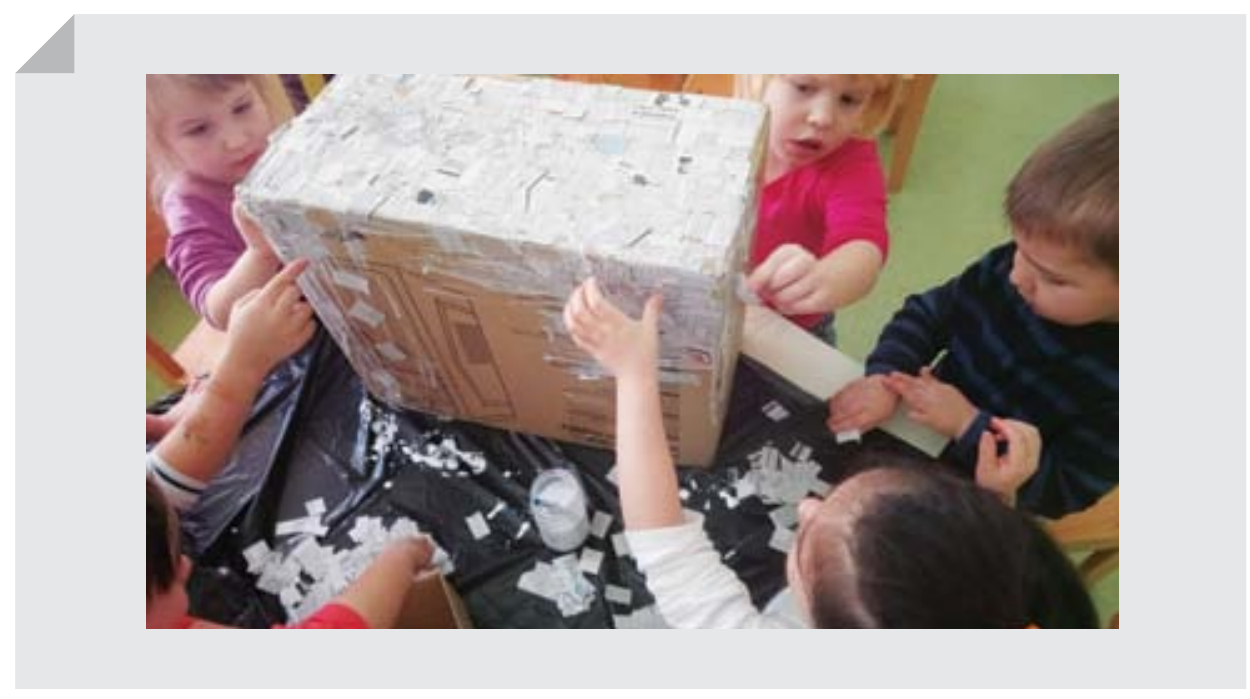




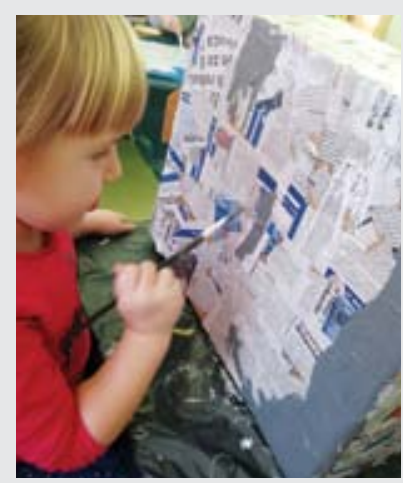

Slika 7.

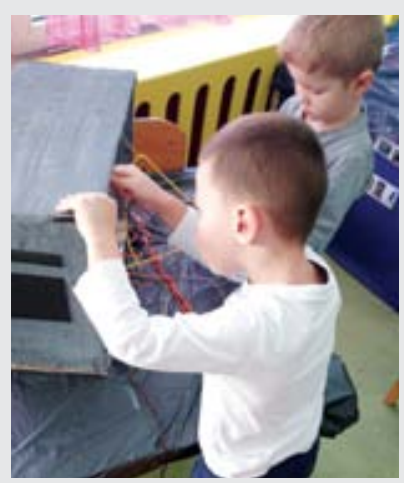

Slika 8.

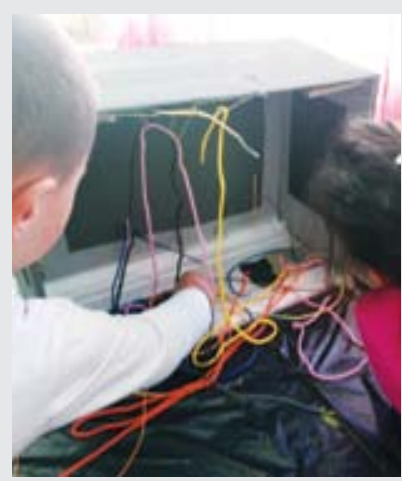

Slika 9.

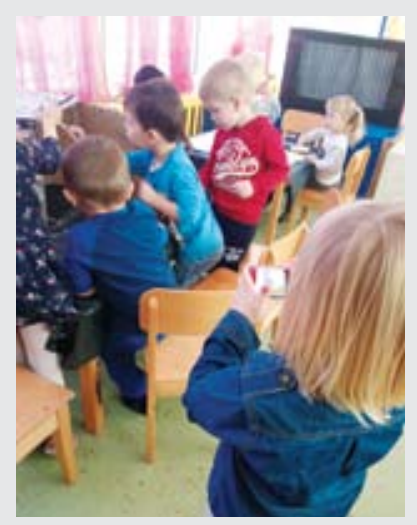

Slika 10

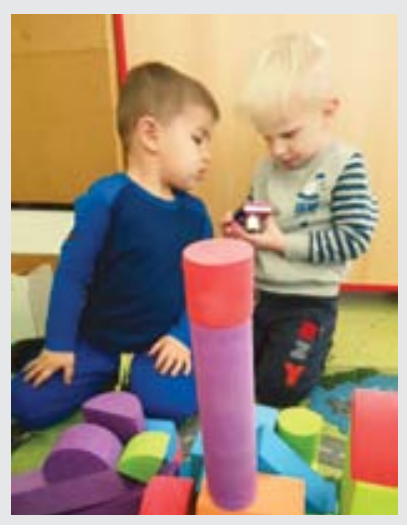

Slika 11.

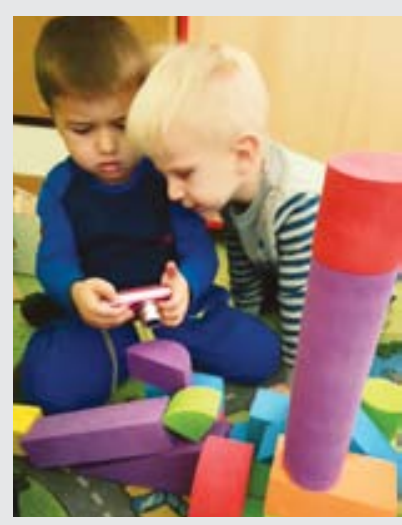

Slika 12

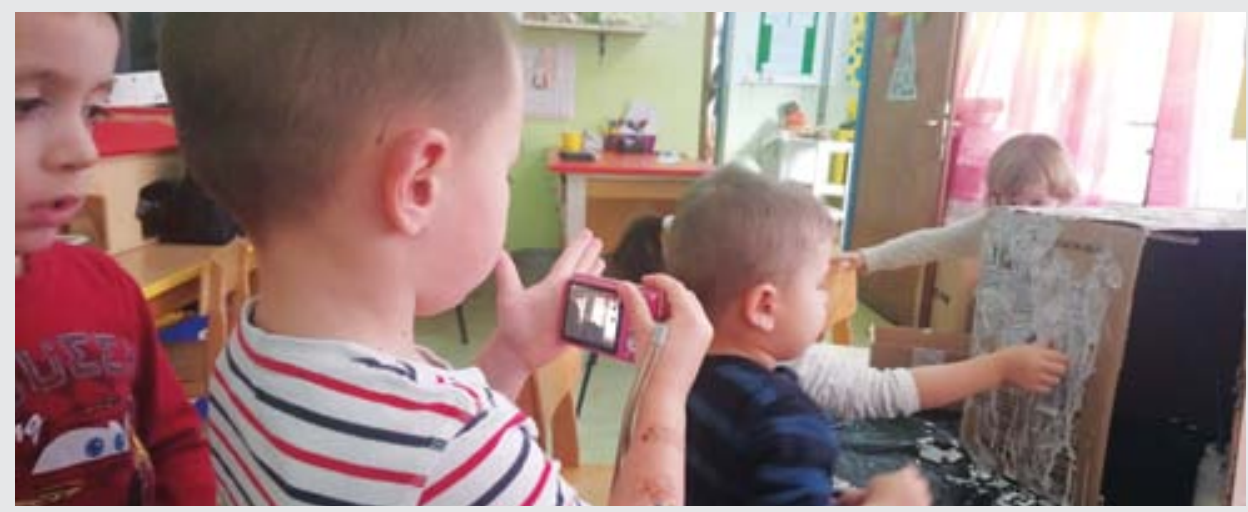

Slika 13. 


\subsection{Pokušaj samostalne izrada medijskog sadržaja - korištenje fotoaparata}

Fotoparat je sasvim slučajno završio u dječjoj upotrebi. Prilikom jedne aktivnosti u pokušaju istovremenog pomaganja djeci i dokumentiranja procesa, mobilni uređaj je pao na pod. Djevojčica je ponudila pomoć. Uzela je mobitel i fotografirala. Idućeg dana provoditeljica projekta je donijela vlastiti, privatni fotoaparat. S obzirom na to kako su ga djeca prihvatila (bio je samo jedan uređaj, postojao je strah da će to biti potpuno neučinkovito jer će samo jedan uređaj prouzročiti svađu, no djeca su pokazala vlastite kompetencije u nekoliko razina. Rukovanje fotoaparatom ide u prilog tome da djeca promatraju kako odrasli koriste uređaj (Slika 10). Oprez i pokušaj namještanja kadra te međusobno pomaganje prilikom fotografiranja značajke su prve upotrebe. Iako smo imali samo jedan uređaj djeca su se dogovarala tko će i kada koristiti fotoaparat. Jedni drugima su objašnjavali kako rukovati fotoaparatom (Slika 11 i Slika 12). Djeca koriste fotoaparat onako kako su ga koristile i odgojiteljice tijekom rada. Pokušali bi neprimjetno fotografirati drugu djecu tijekom njihovih aktivnosti (Slika 13).

\subsection{Posjet Gradskoj knjižnici Vrbovec}

S ravnateljicom Gradske knjižnice u Vrbovcu dogovoren je posjet djece iz vrtića. Ravnateljica je bila iznenađena dolaskom djece $u$ ranijoj dobi jer su većinom $u$ organizirane posjete knjižnici do sada dolazila djeca starijeg predškolskog uzrasta. Primjetili smo da su neka djeca prvi put bila u posjetu knjižnici dok, su nas neki obavijestili da dolaze ovamo sa svojim roditeljima. U dječjem odjelu knjižnice, knjižničarke su pripremile mnoštvo slikovnica. Djeca i odgojiteljice su posudile knjige i odnijele je u vrtić. U knjižnici su se djeca, osim s knjigama, susrela i s procesom posudbe knjiga (članske iskaznice, vraćanja knjiga, posuđivanje novih).

\subsection{Pričanje priča uz pomoć projektora}

Veliki broj djece u skupini nije omogućilo približavanje djece tijekom čitanja pričanja i okretanja stranica u odnosu na format slikovnice. Djeca su htjela biti u blizini odgojiteljica jer su htjela vidjeti ilustracije. Zato je za čitanje slikovnica iskorišten projektor koji vrtić posjeduje. Treba naglasiti da postoje poteškoće s tehničkim dijelom (postavljanje, pronalaženje mjesta i smještanje $u$ jednom dijelu sobe dnevnog boravka, pospremanje), no djeca su pomagala. Pažljivo su pomagali skupiti dijelove kao i kod korištenja fotoaparata. 
Primjećena je duža koncentracija tijekom čitanja uz pomoć projektora, nego kod korištenja same slikovnice. Kada bi ju čitali bez projektora, pažnja nije bilo toliko dugo usmjerena na sadržaj, već na međusobnu komunikaciju. Projektorom je omogućen veliki format i jasna vizualizacija koja svakom djetetu pruža vlastiti prostor za doživljaj priče.

\subsection{Pokretanje vrtićkog lista}

Glavni cilj izrade Vrtićkog lista bio je povezivanje djece iz dislociranih objekata i pokušaj međusobnog upoznavanja s djecom iz ostalih skupina, ali i s formom novina. Vrtićki list prije svega je namijenjen djeci. U prvome broju djeci su predstavljeni objekti i skupine u vrtiću. Kroz novine je djecu vodio Žabac kao autor novina i predstavljao je skupine po objektima. Pozvao je djecu na suradnju s molbom za pomoć u idućem broju. Odgojiteljice su za prvi broj dostavile nekoliko fotografija iz svojih skupina (fotografije trenutnih aktualnosti $u$ skupinama, čime se djeca bave i što je predmet njihovih trenutnih interesa). U svakom je objektu na vidljivo mjesto postavljen sandučić sa slikom Žapca (u centralni objekt te dva dislocirana objekta, tri sandučića sveukupno), u koji su djeca mogla ubaciti svoje prijedloge za idući broj. Djeca u mlađim skupinama prolistala su novine, pratila fotografije Žapca i tražila slike svoje skupine (Slika 14), dok su starije skupine imenovale ostale skupine, odgojiteljice, djecu, braću te prepoznavali prostor dislociranih objekata. Starije skupine su napunile sandučić materijalima za idući broj.

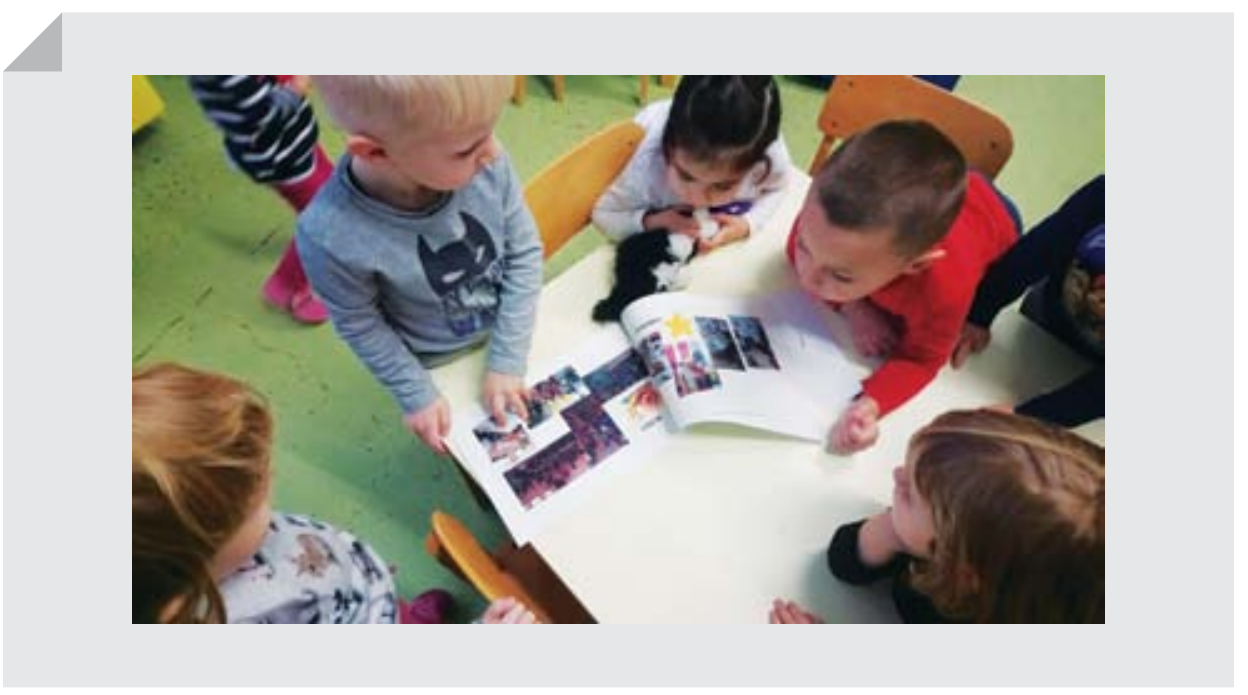




\subsection{Radionica s roditeljima}

Radionica je najavljena sedam dana prije termina održavanja. Putem projektora i prezentacije roditeljima se pokušalo objasniti kako medijski sadržaji utječu na djecu, koje su to specifičnosti oblikovanja pojedinih sadržaja (crtani filmovi, videoigre, oglasi, društvene mreže, televizija, internet) i na koji način djeluju na djecu, ali i na odrasle. Radionica se odvijala interaktivno, s mnoštvom pitanja i komentara roditelja, ali i međusobnih rasprava o pojedinim sadržajima. Roditelji su podijelili svoja iskustva, nedoumice i strahove $\mathrm{u}$ kontekstu korištenja medija. Nakon radionice, putem adrese elektroničke pošte skupine, roditelji su primili korisne izvore daljnjeg informiranja o medijima (primjerice djecamedija.hr, medijskapismenost.hr, commonsensemedia.com), dokumentarne filmove i druge korisne sadržaje. Nakon tridesetak dana ispunili su kratki upitnik o korištenju medija u vlastitom domu. Važno je naglasiti da je na radionici bilo prisutno dvanaest roditelja (od dvadeset i troje djece upisane u skupinu). Moglo bi se pretpostaviti da kod roditelja još uvijek ne postoji razvijena svijest o važnosti medijske pismenosti kod djece. Mnogi su roditelji komentirali da ionako nije „ništa važno“ na roditeljskom pa sigurno neće mnogo propustiti. S druge strane, provedena anketa pokazala je da se roditelji gotovo u potpunosti slažu da njima treba edukacija u vezi odnosa medija i djece. Čak 90 \% roditelja smatra da odgojitelji trebaju educirati i njih i djecu. Kada je riječ o broju sati provedenih u gledanju televizije, 53 \% djece gleda televiziju do jedan sat dnevno, 32 \% djece od jedan do dva sata, dok je onih koji provode tri i više sati ispred televizijskih ekrana $15 \%$.

\subsection{Radionica s odgojiteljicama}

Radionica s odgojiteljicama održana je zbog interesa samih odgojiteljica. Bile su upoznate s projektom i izrazile interes za navedene sadržaje. Ključan je bio poziv za radionicu s roditeljima. Vidjevši navedene tematske cjeline, odgojiteljice su zamolile održavanje sastanka kako bi se i njima predstavile specifičnosti medija u kontekstu ranoga i predškolskog odgoja i obrazovanja. Odgojiteljicama su predstavljene značajke medija u odnosu na djecu, specifičnosti sadržaja i načini utjecaja na djecu, ali i na odrasle. Cilj radionice bio je osvještavanje vlastitih postupaka (primjerice, potičemo li u svakodnevnom radu stereotipe; kako reagiramo kada nam djeca i roditelji donose sadržaje u skupine - crtane filmove, igračke, uređaje i slično; kako koristimo i koristimo li medije u svakodnevnom radu, savjetujemo li roditelje o korištenju medija i kako to činimo). 
Radionica je održana u interaktivnom obliku, s puno promišljanja i konstruktivnih rasprava o ulozi odgojitelja u procesu medijskog opismenjavanja. Nakon radionice, odgojiteljice su ispunile anketu $(\mathrm{N}=22)$. Rezultati su pokazali da $81 \%$ odgojiteljica smatra da bi odgojitelji trebali poticati razvoj medijske pismenosti, dok se 95 \% slaže s tvrdnjom da su medijsko opismenjavanje odgovorni i roditelji. Tek 23 \% odgojiteljica smatra da njihova ustanova pruža mogućnost za korištenje medija u radu. Kao i kod rezultata ankete s roditeljima, treba uzeti u obzir mali uzorak te moguće davanje poželjnih odgovora.

\section{Zalključalk}

Projekt je pokrenut iz motivacije za osvještavanjem važnosti medija u okruženju ranoga i predškolskog odgoja i obrazovanja i promišljanja mogućnosti za razvoj medijske pismenosti djece. U vrtićima smo svjedoci različitih poruka koje roditelji prenose djeci, a nisu vjesni dugoročnih posljedica takvog načina komunikacije. Često već ujutro, pri dolasku u vrtić, čujemo obraćanje djeci u obliku toga da će, za nagradu, ako budu „dobri“ u vrtiću, kod kuće „dobiti mobitel i laptop“, ili pak ako ne „budu dobri“ neće „dobiti“ spomenute uređaje. Osim uvjetovanja uređajima, često je i poticanje stereotipa i rodnih razlika.

Roditelji imaju percepciju medija iz svoga djetinjstva, kada su u ih svojoj dječjoj dobi drugačije koristili nego što ih djeca koriste danas. U cilju projekta nije bilo samo isticanje negativnih strana medija, već i pokušaj prikazivanja mogućnosti za korištenje medija u obrazovne svrhe i stvaranja korisnih dječjih navika u odnosu na medije već od rane dobi. Djeca su, s druge strane, doista spremna na izazove, međusobnu suradnju i pomoć drugoj djeci i odraslima.

Vlastita, početna nesigurnost (odgojiteljice) proizlazi iz nedovoljno dostupnih materijala koji bi mogli usmjeriti rad $\mathrm{u}$ odgojno-obrazovnim skupinama $\mathrm{u}$ vrtićima. $\mathrm{S}$ roditeljima djece u ranoj, jasličkoj dobi, potrebno je krenuti raditi na jačanju njihovih vještina čim se djeca upišu u ustanove. Potrebno ih je pripremati, usmjeravati, informirati i upućivati na mogućnosti i izazove koji su danas prisutni u medijskim sadržajima. Dob kao jedan od ključnih faktora utjecaja medija na dijete $u$ ranom i predškolskom odgoju nameće obavezu odgojiteljima za rad sa svima uključenima u odgoj i obrazovanje djeteta. Odgojitelji zbog svog neposrednog kontakta i rada s djecom na neki su način posrednici između roditelja $i$ djece, između medijskog sadržaja i djece, potpora roditeljima te ostalim profesionalcima koji rade u odgojno-obrazovnom procesu u ranoj i predškolskoj dobi. Zato je nužno da 
su educirani i da neprestano obnavljaju znanja i vještine kako bi mogli pružiti kvalitetnu podršku u procesu. Često se spominje nedostatak materijalnih sredstava u vrtićima (opremljenost medijskim uređajima) i nepostojanje edukacija za stručnjake. Svakako treba ustrajati na potpori odgojiteljima tijekom inicijalnog obrazovanja odgojitelja, ali i na kreiranju daljnjih edukacija za sve one koji već rade u odgojno-obrazovnim ustanovama. Kreiranje metodičkog kolegija, s konkretnim načinima rada te shodno tome i kreiranje priručnika o primjeni u praksi, nužni su koraci u daljnjem poticanju medijske pismenosti djece i doprinosa razvoju njihovih medijskih kompetencija. Moramo biti svjesni da medijska pismenost i medijske kompetencije ne podrazumijevaju samo snalaženje $u$ upotrebi medijskih sadržaja i sredstava, već unutar socijalnog konteksta snažno utječu na oblikovanje identiteta djeteta. Potrebno je razvijati medijsku pismenost kao i sve druge socijalne vještine u okviru „medijskog djetinjstva“ kako bi se ublažili utjecaji konstruiranih medijskih slika stvarnosti. Medijsku pismenost nikako ne smijemo zanemariti u današnje vrijeme, nužno je što više o tome govoriti i prenositi svima koji sudjeluju u odgoju i obrazovanju djece.

S obzirom na učinke na dijete $u$ ranoj dobi, nužno je pokretanje inicijativa za održavanje radionica i edukacija u vrtićima na području Republike Hrvatske. Potrebno je osvijestiti i lokalne zajednice i pokušati okupiti roditelje djece koja nisu uključena u odgojnoobrazovne ustanove. Prema Državnom zavodu za statistiku (DZS, 2018) u programe ranog i predškolskog odgoja uključeno je $17,2 \%$ djece do tri godine, $36,1 \%$ djece od tri do pet godina i 46,7 \% djece od pet do sedam godina. Podaci upućuju na velik broj djece izvan odgojnoobrazovnih sustava kojima također treba potpora u razvoju medijske pismenosti. Kada se djeca uključe u obaveznu predškolu, već imaju oblikovane svoje stavove i propuštena je mogućnost za intervencije i djelovanje na dječje spoznaje temeljnih stavova, vještina i znanja u odnosu na medije.

Slaba posjećenost radionice za roditelje u sklopu projekta ukazuje na slabo razvijenu svijest o utjecajima medija. No, ipak, nakon radionice i prijenosa informacija između roditelja, bilo je upita za ponovne sastanke i daljnje edukacije. Dakle, nakon što roditelji vide i čuju o čemu je riječ, interes za temu raste. Projektom se potaknulo dvadesetak roditelja i odgojitelja koji su zainteresirani za daljni rad na vlastitim sposobnostima i vještinama. Stoga svakako vrijedi ustrajati i povećavati broj uključenih osoba za kreiranje poticajnog okruženja za rast i razvoj djeteta u suvremenom okruženju punom medijskih izazova. 


\section{Popis literature}

- Bartaković, S., Sindik, J. (2016). Medijacijska uloga roditelja prilikom djetetovog gledanja televizije. Acta Iadertina, 13 (2), 95 -113.

- Ciboci, L., Kanižaj, I., Labaš, D.(ur.) (2011). Djeca medija. Od marginalizacije do senzacije. Zagreb: Matica hrvatska

- Ciboci, L., Kanižaj, I., Labaš, D. (2014). Media Education from the Perspective of Parents of Prechool Children: Challenges and Trends in Free Time Media Use. Medijska istraživanja, 20 (2), 53-69

- EC (2007). Key competences for lifelong learning - European Reference Framework. Dostupno na: http://eur-lex.europa.eu/ legal-content/EN/TXT/?uri=uriserv\%3Ac11090. Preuzeto 15. studenoga 2017.

- EC (2011). Council conclusions about early choldhood education and care: providing all our children for the best start of the world of tomorrow. Dostupno na: https://www.consilium.europa.eu/uedocs/cms_data/docs/pressdata/en/educ/122123.pdf. Preuzeto 28. prosinca 2017.

- MZOS (2014). Nacionalni kurikulum za rani predškolski odgoj i obrazovanje. Dostupno na: http://www.azoo.hr/images/ strucni2015/Nacionalni-kurikulum-za-rani-i-predskolski-odgoj-i-obrazovanje.pdf. Preuzeto 10. studenoga 2017.

- Ministarstvo obrazovanja Sjedinjenih Američkih Država (2016). Early Learning and Educational Technology Policy Brief. Dostupno na: https://tech.ed.gov/earlylearning/ Preuzeto 1. prosinca 2017.

- Malović, S., Maletić, F., Vilović, G., Kurtić, N. (ur.). (2014). Masovno komuniciranje. Zagreb: Golden marketing - Tehnička knjiga.

- Mikić, K. (2002). Mediji i dječja svakidašnjica. Dostupno na: http://www.hfs.hr/nakladnistvo_zapis_detail.aspx?sif_clanci=213\#. WmJNN66nGM8. Preuzeto 4. prosinca 2017.

- OECD (2001). Starting strong I. Dostupno na http://www.keepeek.com/Digital-Asset-Management/oecd/education/startingstrong-ii_9789264035461-en\#page1. Preuzeto 25. studenog 2017.

- OECD (2006). Starting strong II. Dostupno na: http://www.keepeek.com/Digital-Asset-Management/oecd/education/startingstrong-ii_9789264035461-en\#page1. Preuzeto 25. studenog 2017.

- Sindik, J. (2012). Kako roditelji percipiraju utjecaj medija na predškolsku djecu? Medijska istraživanja, 18 (1), 5-33.

- Tolić, M. (2009). Temeljni pojmovi suvremene medijske pedagogije. Život i škola, LV (22), 97-103.

- Zakon o predškolskom odgoju i obrazovanju. Narodne novine 10/1997, 107/2007, 94/2013

- Zgrabljić Rotar, N. (ur). (2005). Medijska pismenost i civilno društvo. Sarajevo: Mediacentar 


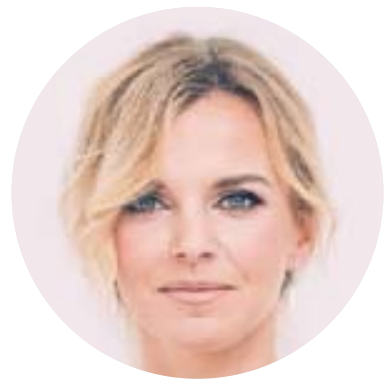

\section{Kristina Ljubić Nežić}

Kristina Ljubić Nežić rođena

je u Zagrebu 1986. godine. Osnovnu školu i Opću gimnaziju završava u Vrbovcu. 2005. upisuje preddiplomski studij Predškolski odgoj na Učiteljskom fakultetu u Zagrebu. Stručna prvostupnica predškolskog odgoja postaje 2008. godine. Pripravništvo i daljni rad nastavlja u dječjem vrtiću Vrbovec gdje radi i danas. 2017. godine diplomirala je na Učiteljskom fakultetu u Zagrebu na diplomskom studiju Rani i predškolski odgoj i obrazovanje. Studentica je poslijediplomskog specijalističkog studija Organizacija i menadžment na Ekonomskom fakultetu Sveučilišta u Zagrebu. 